\title{
The Adequacy of the Teaching Practice Supervision observation instruments for the Post Graduate Diploma Students of Zimbabwe Open University (ZOU): A case study of Midlands Region ZOU
}

\author{
Thondhlana Saiden \\ Lecturer: Department of Educational Studies ZOU
}

\begin{abstract}
The purpose of the study was to establish the adequacy of the Teaching Practice observation instruments for the Post Graduate Diploma (PGDE) of the ZOU. The instrument was studied in terms of how it addressed before lesson delivery activities, during lesson activities, after lesson activities and personal dimensions. The sample consisted of 16 supervisors and 19 student teachers conveniently sampled. A qualitative research methodology was adopted. The study established that the instruments generally had most issues but mark allocation needed separation, the instruments, could not be attended to objectively in the single lesson of supervision. It was recommended marks should be debunched, a variety of instruments attending to certain areas be used and the supervision time to be increased.
\end{abstract}

Keywords: Adequacy, Teaching Practice, Supervision instruments, Post Graduate Diploma in Education

\section{INTRODUCTION}

Teaching practice is an essential aspect of teacher education as it forms the core of the teacher training programme. Teaching Practice is to acquaint student teachers with the practical knowledge of teaching and learning. The Post Graduate Diploma in Education Students of the ZOU are supposed to wrap up their course with Teaching Practice in their last semester which is the third semester. Teaching Practice according to Salawu and Adeoye (2002) cited in Celawu, Salawu and Osuji (2008) is a practical teaching activity by which student teachers are given an opportunity in actual school situation to demonstrate and improve training in pedagogical skills over a period of time. Teaching Practice is intended to result in effective teachers.

Meador (2014) enumerates ten qualities of an effective teacher. First, an effective teacher loves to teach, an effective teacher can relate to his or her students and an effective teacher uses different strategies to reach every student. Second, an effective teacher is an effective communicator, an effective teacher is proactive and an effective teacher strives to be better that is, looks for new and better teaching strategies. Third, an effective teacher uses a variety of media, an effective teacher challenges his/her own students and an effective teacher understands the content he/she teaches.

During the Teaching Practice mentors, school administrators and University supervisors assess and supervise the student teachers. In the assessment and supervision instruments are used. The instruments used should enable the assessment of whether the students are becoming 
effective teachers that is, whether they have acquired the required skills, knowledge and attitudes required of a teacher.

Muzata and Penda (2010) had these under activities before teaching, that include planning and scheming and classroom arrangement, activities during the lesson and activities after the lesson. They came up with forty four issues to be assessed. Bhowmik, Banerjee and Banerjee (2013) indicated that the following areas are to be assessed and supervised; organisation and clarity, dynamism, instructor and group interaction, student motivation and engaging students through questioning.

This paper argues that the issues associated with effective teaching require the use of a variety of instruments to enable effective assessment. The instruments should allow the teacher to comprehend where he or she is legging behind and hence take corrective action. Cohen (1976) documents a number of issues include the following; teacher's contacts with pupils (Adam) a ration measure of teacher dominative / integrative behaviour (Hoeln, teacher verbal behaviour (Wiseman and Aaron) and teacher classroom organisation and method scale to state a few. Other areas to be assessed include ability to scheme, plan and keep records and teacher instruction with pupils.

Since of lot of issues are to be attended to, in the ZOU the assessment is done in one lesson which is approximately thirty five or forty minutes. This time, the researcher has experienced is not sufficient to cover all areas of teaching. Further, a number of assessments instruments have been developed. These instruments include rating scales (Lin and Grounlund, 1995) numerical rating scales (Lin and Groundlund, 1995) the descriptive graphical rating scales and frequency tabulation or coding schemes (Flanders, 1994). The ZOU uses the descriptive rating scale for students on teaching practice. The instrument used from the research experience does not cover some of the issues related to effective teaching and does not cover areas fully. The time for the supervision and assessment seems to be short for it is carried out in one semester and each supervision session takes 35-40 minutes. Lewin (2004) established that such short sessions give student trainee little insight into children's development or the durability of their learning that may take place. Madavanhu (2014) discovered differences between teacher educators and mentors that is University lecturers considered their assessment to be more valid than those of mentors and for this reason were hesitant to take mentor's views.

\section{STATEMENT OF THE PROBLEM}

There is a problem of the inadequacy of time to attend to all issues related to assessment of post Graduate Diploma in Education students on teaching practice in the ZOU. This study aims at answering the following questions:

What is the adequacy of the assessment of Post Graduate Diploma in Education students on teaching practice in the ZOU Midlands Region?

\section{Research Sub-questions:}

The study answered the following sub-problems:

1) To what extent do the supervision instruments address the activities before lesson delivery?

2) To what extent do the supervision instruments address lesson delivery activities?

3) To what extent do the supervision instruments address class and classroom management skills? 
4) To what extent do the supervision instruments address the personal dimensions aspect?

5) How do supervisors and students conceive the objectivity in the use of the instruments in the time available for supervision?

\section{PURPOSE OF THE STUDY}

The study was aimed at establishing the adequacy of the Teaching Practice Supervision Instrument used in the assessment of the PGDE students in ensuring the creation of a teacher who has the required qualities of a teacher.

\section{SIGNIFICANCE OF THE STUDY}

The study was significant in a number of ways. It was significant to the Department of Teacher Development of the ZOU in that it should identify the shortcomings of the supervision instrument and hence take corrective action. The study could also lead other teacher training institutions identifying shortcomings of their own TP supervision instruments. The students would benefit from the study in that their TP would touch on all areas that would equip them with all skills, knowledge and attitudes requires for the trade. The Ministry of Primary and Secondary Education will also review its own supervision instruments against the findings of the study.

\section{DELIMITATIONS OF THE STUDY}

The study was delimited to the PGDE students of the ZOU Midlands Regional Campus. It was also delimited to issues related to the adequacy of the TP supervision instruments used on the PGDE students.

\section{Conceptual Framework}

\section{LITERATURE REVIEW}

Teaching practice is viewed by Faghulu (1984) in Celawu, Salawu and Osuji (2008) as a kind of apprenticeship stage during which students are sent to school to gain practical and professional experience by translating all the educational theories they have acquired or learnt during training into practice. Yee (1967) is cited by Celawu, Salawu and Osuji (2008) define teaching practice as a prolonged period of laboratory experience in an actual classroom situation during which the student takes increasing responsibility for his/ her teacher education centre and co-operating for the classroom situation. Teaching practice from the above is carried at the end of training to assess the mastery of knowledge, attitudes and skills in student teachers for the purposes of helping student teachers to become full-fledged teachers and assessing this mastery. This is done through school based supervisors and university supervisors.

Supervision is defined by Goldhammer, Anderson and Krajewski (1993, p. 31) as 'those activities that improve the quality of teaching and stimulate professional growth and the attainment of "stretch" goals of all participants, thereby nurturing a healthy, invigorating and effective work culture'.

This definition emphasises supervision is intended to improve quality of teaching through staff development activities. 
Harris (1985, p .10-11) view supervision of instruction as, what school personnel do with adult and things to maintain or change the school operation in ways that directly influence the teaching process employed to promote pupil learning.

In the above definition adult include student teachers and things are the materials and financial resources used in teaching which is to keep or better the standards of teaching and the learning process in schools.

Carrol (2007, p36) cited in Mudavanhu (2014) view supervision as 'a forum where supervisees review and reflect on their work in order to do better'. Supervision there should not be adjudicatory but should involve the students.

Observation instruments are tools which involve a selection and encoding of a set of natural behaviours or other naturally observed behaviour (Judd, Smith, \& Kidder, 1991). Observation instruments could be in the form of equipment or forms used in the recording of behaviour seen or recording an event taking place at a particular place at a particular time (Tullock, 1993, p. 789).

\section{Theoretical Framework}

The study was premised on the production function theory. The production function theory has inputs that determine the processes that lead to outcomes or products (Coates, 1998).

\section{Empirical Literature Review}

For a teacher to be effective Bhowmik, Barorjee and Banerjee (2013) point out the following tenets:

1) Realisation that pupils learn best in positive and nurturing environment established by teachers who believe that every pupil is capable of learning.

2) Realisation that all pupils have areas of strengths and interest that can be useful in advancing pupil learning.

3) Teachers take into account whole pupil. They attend to cognitive, affective, social and physical dimensions when developing an instructional programme.

4) Realisation that there should be active engagement and the need to be interactive to facilitate learning.

5) Realisation that new learning is built upon previously learnt information. Learning is enhanced when prior knowledge and cultural and social experiences are valued, acknowledged and leveraged and a

6) Realisation that pupil's learning is both individually and socially. The learning is influenced by the cultural, familiar and social context.

Celawu, Salawu and Osuji (2008) discuss ten student teaching practice goals. The first is that teaching practice should; provide opportunities to learn the art of teaching, provide opportunity to demonstrate real classroom situation mastery of teaching the subject matter and methodology of imparting it to learners. The second is that of providing professional development and fostering a positive spirit to teaching. They state the following objectives of Student Teaching Practice; 1. Ensuring development of skills and competencies of teaching, applying principles learnt at university, writing schemes of work and lesson notes using appropriate concepts. 2. Making of generalisations that will facilitate learning, selection and use of a variety of teaching strategies. 3. Use of instructional resources that are appropriate to achieve the objectives stated in the lesson plans, studying and diagnosing learning difficulties 
of pupils. 4. Ensuring the provision of guidance and remedial instruction to those who need them and applying the principles of evaluation in assessing the effectiveness of teaching as means of improving instruction. 5. Ensuring the achievement of skill in democratic classroom management, participating actively and effectively in the various instructional programmes and activities of school where one is on Teaching Practice and 6. Ensuring the establishment of good human relations with students, staff and parents and having the opportunity to participate in community activities.

Meador (2014) documents ten qualities of an effective teacher as, one who loves to teach. One who relates to his/her students, one who is willing to think outside the box that is realising that children learn differently, one who is willing to be creative and adaptive in lesson, one who is an effective or excellent communicator, one who is proactive rather than reactive, one who strives to be better that is looking for new or better teaching strategies, one who uses a variety of media in their lessons, one who challenges their students and one who understands the content that they teach and knows how to explain that content. Antony and Walshaw (2009) agree with the characteristics pointed by Meador above. These issues should constitute the elements on supervision forms.

The Ministry of Primary and Secondary Education narrative supervision report on a teacher has the following aspects; professional knowledge and understanding covering academic qualifications, professional qualifications, subject specialisation, self-advancement, curriculum, syllabus interpretation, scheming and lesson planning and record keeping; professional skills and abilities entailing teaching and learning with teaching load, lesson presentation and written work, classroom organisation and management with class motivation and control and evidence of continuous formative assessment; teacher personal reflection and communication entailing self-evaluation, classroom based action research and evidence of effective communication, professional values and personal commitment comprising professional development, participation in professional school and community networks, departments, attire, attitude to work and advice, involvement in sporting and cultural activities and willingness to go an extra mile, in class. Remediation, learner care, protection, conclusion and recommendations comprising strengths, areas of improvement, challenges and recommendations are also included.

The Mkoba Teacher's College Teaching Practice supervision and assessment form has the following aspects; preparation and planning comprising general planning, scheming and sequencing of topics, register, individual progress record, remedial and extension record, child study, objectives of the lesson, introduction to lesson, selection and sequencing of content and closing the lesson; teaching procedures comprising generating class interest, media and chalkboard work, teacher's use of language, teacher/pupil interaction, pupil/pupil interaction, questioning and appropriate pacing of lesson; class management and control consisting of focusing pupils attention, organising children; closing lesson, lesson objectives achieved and overall comment.

Walker (2008) made student trainers write an essay on the most memorable teachers that is those who had great impact on their lives and were most successful in teaching the subject matter. The student trainees identified twelve persona and professional characteristics of effective teachers namely; being prepared, being positive, being available to student, holding high expectations, being creative, being fair, displaying a personal touch, cultivating a sense of 
belonging, being compassionate, having a sense of humour, respecting students, forgiving and admitting mistakes.

Weimer (2009) highlight six key characteristics of effective teachers that are; having interest and providing explanation, having concern and respect for students and students' learning, using appropriate assessment and providing reasonable feedback, having clear goals and intellectual challenge, being independent and actively involving students and learning from students. The Stanford University (undated) cite Hilderbrand (1971) agreeing with the above stated characteristics.

In Zambia Student Teaching Practice supervision and assessment looks at subject files, schemes of work and record books, lesson delivery, choice and use of teaching and learning aids, pupil's participation, achievement of lesson objectives, knowledge of subject matter as well as work relationship with head of departments and school administration (Mazata and Penda, 2010, p. 195). Mazata and Penda (2010) list forty-four aspects that are observed in the assessment of students. These aspects are; student voice projection, knowledge of subject, board work clarity and order, capturing learner's attention, planning lessons, rapport with children, using pointer, connecting previous lesson to new lesson, teaching from known to unknown, lesson coherence, supervision of group activities, communication abilities, involving learner in lesson reflection, teacher's confidence, time management, disruption discussion method, relating lesson to real life, providing clear instructions to learners/questions, use of teaching and learning aid, real objects as teaching and learning aid, evaluating previous lesson, summarising lessons, connecting lesson to next lesson, discouraging chorusing, facing class while teaching, correcting board mistakes, asking thought provoking questions, lesson learner centred, motivation, classroom control, poor eye contact/ not knowing learner's names, using right chalk colour, matching teaching aids to lesson, matching content to intellectual level, correcting behaviour, dress, lesson conclusion, conclusion with questions, conclusion by highlighting main points learnt, conclusion by marking some exercises, keeping answers on board when asking questions, class exercise after teaching, checking lesson plan by Head of Department and inclusive strategies.

\section{Research Design}

\section{RESEARCH METHODOLOGY}

The research adopted the qualitative research methodology. It was a case study of the Midlands ZOU Region. . Case studies elicit in-depth understanding of a particular situation (Fisher, 2004). The case study was also chosen for it allowed the researcher to gather a wealth of information about the supervision instrument (Yin, 1984).

\section{Population, Sampling and Sampling Procedures}

The study employed convenient sampling. Convenient sampling was ideal because the students operate away from the campus and the study was undertaken when the students were not meeting as a group. The target population was the 169 PGDE Intake 14 students, 16 university lecturers and 154 school based mentors. The study had a sample of sixteen supervisors comprised of six school based mentors and ten university lecturers and nineteen students who were conveniently sampled. The mentors were those that the researcher contacted as he went out on Teaching Practice Supervision. Supervisors were in the team that supervised the PGDE intake 14 students in early February 2016. These were conveniently sampled. The students were the ones the researcher visited as he supervised those on Teaching Practice. 


\section{Instruments and Data Generation Procedure}

The students filled in open ended questionnaires and were interviewed. The supervisors filled in open ended questionnaires and were interviewed. Also the ZOU TP supervision assessment forms were analysed. Some students were interviewed as they came for other business to the ZOU Midlands Regional Campus Offices.

\section{Data Analysis Procedures}

Qualitative data analysis was undertaken through coding, finding emerging trends and themes. The researcher followed Meriam's (2009) analysis of qualitative data namely organising and preparing data, reading and re-reading data, noting relationships after identification of themes and the choice of one category and noting the relationships of categories.

\section{Ethical considerations}

Ethical considerations of confidentiality, informed consent, not harming the subjects and anonymity were assured during the study. Respondents were requested not to write their names as they responded to questionnaires. The participants completed informed consent forms. The participants were also informed they could discontinue from participation at any stage they so wished.

\section{FINDINGS AND DISCUSSION}

The findings cover biographical data of informants and the participants and informants reactions to the six sub-problems of the study.

Bio- Data

Table 1: Bio-data of Supervisors N= 16

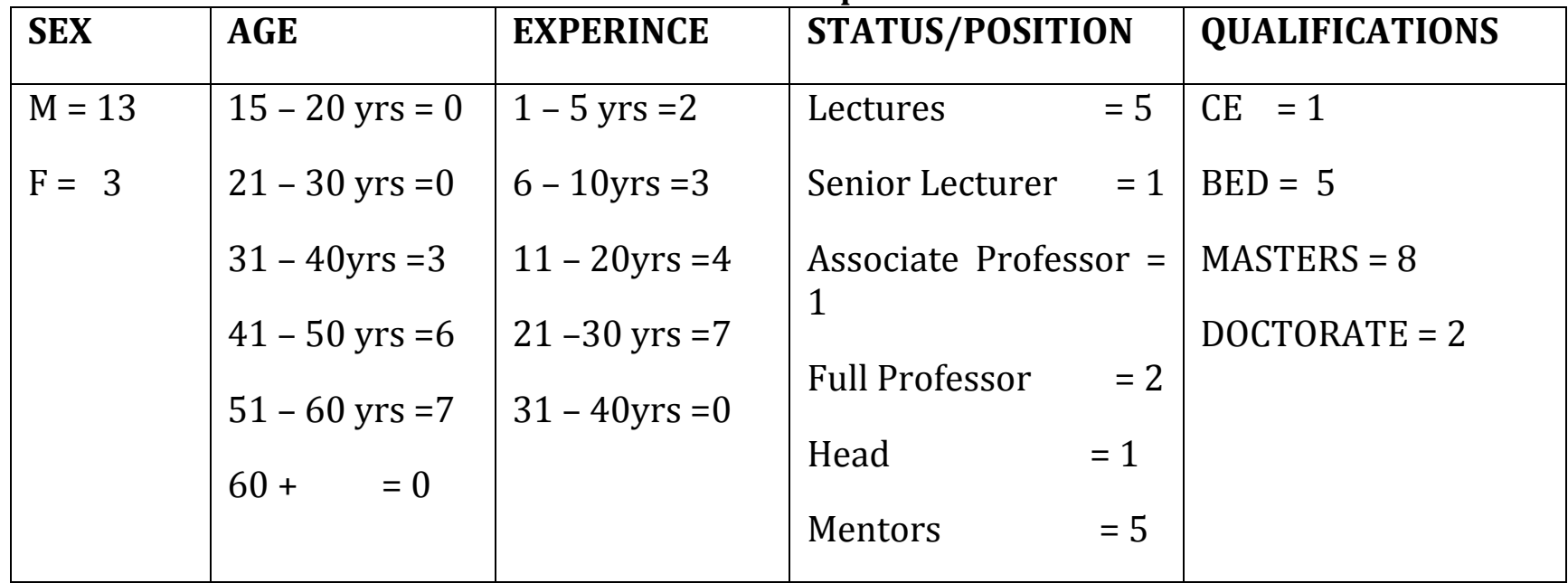

Table 1 show that there were 13 male and 3 female informant supervisors. The age of the informant supervisors ranged from 31 to 60 years. Three (3) were in the age range 31- 40 years, 6 were in the age range $41-50$ years while 7 were in the age range $51-60$ years. The ages reflect that the informants were quite mature. In terms of experience the informants experience range from $1-30$ years. There were 2 in the experience range 1- 5 years. There were fairly new in the field. There were 3 in the experience range $6-10$ years, 4 in the $11-20$ years' experience range and 7 in the 21 - 30 years' experience range. These were quite experienced to be in a position to give quite valuable information. In terms of status the table reflected that 5 were Lecturers, 1 was a Senior Lecturer, 1 was also an Associate Professor and 2 were Full Professors. These informants were quite experienced hence might have provided 
valuable information. With regards to qualification 1 has a Certificate in Education qualification, 5 were Bachelor of Education holders, 8 were Masters of Education holders and 2 were Doctorate holders. Most were highly qualified to give valuable information.

Table 2: Bio-data of Students N = 19

\begin{tabular}{|l|l|l|l|}
\hline SEX & INTAKE & AGE & EXPERIENCE \\
\hline $\mathrm{M}=8$ & $13=1$ & $15-20 \mathrm{yrs}=0$ & $1-5 \mathrm{yrs}=13$ \\
$\mathrm{~F}=11$ & $14=18$ & $21-30 \mathrm{yrs}=5$ & $6-10 \mathrm{yrs}=5$ \\
& & $31-40 \mathrm{yrs}=13$ & $11-20 \mathrm{yrs}=1$ \\
& & $40+\mathrm{yrs}=1$ & $20+\mathrm{yrs}=0$ \\
\hline
\end{tabular}

Table 2 shows there was one (1) intake 13 informant who had fallen behind her group and eighteen (18) intake 14 informants. The ages of the student teacher informants ranged from 21 $-40+$ years. These informants were in the majority mature. The student teachers were 13 with 1 - 5 years' experience. These were fairly experienced in their teaching. Five (5) had $6-10$ year's experience which was quite good for them to give valuable information regarding the teaching supervision instrument. One had 11 - 20 years' experience which implies he had extensive experience to give valuable information regarding the teaching supervision instrument.

\section{The Extent to Which the Teaching Practice Supervision Instrument Addressed Activities Before Lesson Delivery}

A documentary analysis of the ZOU Teaching Practice Supervision assessment form revealed that the form targets scheming and targets on adequacy and up to datedness, quality of preparation, format of schemes, content breakdown and evaluation comments. The Ministry of Education narrative report only pointed out scheming but did not state the areas regarding scheming to be assessed. The Mkoba Teachers College Teaching Practice Supervision and assessment form had scheming and sequencing of topics and nothing more. Celawu, Salawu and Osuji (2008) refers to writing of schemes of work, lesson notes and using appropriate concepts and generalisations that will facilitate learning, selecting and use of a variety of teaching strategies and instructional resources that are appropriate lesson aims. It would appear the assessment form covers much ground on scheming. The area is given a blanket mark. The various areas could have been divided into various parts. The student informants and supervisors informants agreed that the area of scheming is adequately covered agreeing with the documentary analysis of the supervision form.

A documentary analysis of the ZOU Teaching Practice Supervision assessment form also revealed that lesson planning is targeted. Aspects under lesson planning include; lesson objectives; clearly stated and Specific, Measurable, SMART, format of detailed lesson, content sequencing, Pupil / Teaching activities and reflective evaluation. The Ministry of Education narrative form does not include details on lesson planning as does the ZOU instrument. The Mkoba Teachers' College teaching Practice Supervision and assessment form has a portion on general planning but does not stipulate aspects to be looked at as does the ZOU form. It would 
appear the area on planning is well covered except that the marks are not allocated to the respective areas. A blanket mark is given.

The student informants $100 \%$ agreed that the area of planning is well covered and the supervisor informants $100 \%$ also concurs that the planning area was well covered.

Muzata and Penda (2010) however include issues like relating lessons to real life, connecting previous lessons to new lesson in the introduction, stipulating learning aids and summarising the lesson. These aspects are not included in the ZOU assessment form.

\section{The Extent to which the TP Supervision Instrument Addresses Activities During the Lessons}

The ZOU TP assessment form includes lesson delivery which covers; lesson introduction, relevance, skills development, pacing of activities, subject mastery, teaching strategies, relevancy and use of a variety of strategies, media availability and its effective use, teacher / pupil and pupil / pupil interaction, pupil participation and learning, lesson conclusion organisation of learning activities and questioning techniques. The marks on the achievement of lesson objectives are not allocated to sections but given blanketly. Mazata and Penda (2010) point out the involvement of learners in the lesson, lesson coherence, matching content to time management, use of media, summarising the lesson achievement of lesson objectives and marking some exercises. Mazata and Penda (2010) include issues like class exercise after teaching, relating lesson to real life and involving learners in lesson reflection issues not on the ZOU TP Supervision instrument. The Mkoba Teachers' College Practice Supervision and assessment form includes objectives of lesson, introduction to lesson, selection and sequencing of lesson, closing the lesson, media and chalk work, teacher's use of language, Teacher / pupils interaction, pupil /pupil interaction, questioning and appropriate pacing of the lesson. Most of the aspects in the form are also on the ZOU instrument except chalkboard work.

While the student informants $100 \%$ reflected this area was well covered the supervisors reflected it was inadequate. They reflected the inadequacy was in the areas of chalk work, relating lesson to life and involvement of learners in lesson reflection.

The ZOU assessment form includes class and classroom management aspects. These aspects include; organising of group work, management and class control, clarity of instructions, catering for individual pupil needs, appropriateness of pupil tasks and rapport with pupils. Mazata and Penda (2010) have the following issues to be accessed that relate to class and classroom management and control; the teacher encouraging learner confidence, supervision of group activities, rapport with children, facing class while teaching, discouraging chorusing, facing class while teaching, lesson being learner-centred, good eye contact, knowing learners by name and correcting behaviour. It should be noted that ZOU TP Supervision forms left out issues like facing class while teaching, discouraging chorusing and knowing learners by name. The Mkoba Teachers College TP Supervision form under classroom management and control has the following aspects; focusing pupil's attention and organising children that are aspects that agree with some issues in the ZOU instrument.

The Student teacher informants $100 \%$ indicated that marks for the respective aspects should be given instead of giving blanket marks for whole area. They also reflected that there is need to involve mentors in coming up with the areas to be assessed in this area an issue that is emphasised by Mudavanhu (2014). Supervisor informants (100\%) indicated that the areas 
that were pointed out by Mazata and Penda (2010) which are not reflected in the ZOU form need to be included.

\section{The Extent to which the TP Supervision Instrument Address Activities After Lesson Delivery}

The documentary analysis of the ZOU TP assessment forms reflected that the activities after lesson delivery covers issues related to records. The records to be assessed include the teaching practice file, Register, Progress record, Social Record, Remedial Record, pupils written work, Inventory Record, Extension Work Record and resource materials. There are no marks allocated to the respective records but a blanket rating is given for the area. The Ministry of Primary and Secondary narrative supervision report on a teacher has sections on supervision of pupils' work, record keeping, remedial and extension work and maintenance of records to standard. The Mkoba Teachers College TP supervision and assessment form has the assessment of registers, individual Progress Record, Remedial and Extension Record and Child Study Record. These are in agreement with the ZOU TP issues to be assessed related to after lesson delivery.

The student informants felt marks were supposed to be allocated according to the areas. The supervisor informants also agreed with the students. Both students and supervisors felt aspects of written exercise book assessment were to be stipulated.

\section{The Extent to which the TP Supervision Instrument Address Personal Dimensions Aspects}

The documentary analysis of the ZOU TP assessment form reflected the following personal dimensions' aspects were addressed; attire / dress, attitude and conduct, reflection of professional skills, team work, problem-solving, creativity and involvement in co-curriculum activities. These aspects agree with Celawn, Salawu and Osuji (2008) views of establishing good relations with students, staff, parents and other members of the community and having the opportunity to participate in community activities.

The student informants and supervisor informants agreed that the TP supervision instrument covers adequately the issue of personal dimensions but left out community activity involvement.

\section{Conception of Objectivity in Time for Supervision in Relation to Supervision or Assessment of TP}

The students (80\%) and supervisors (90\%) informants claimed that the supervision instrument covers much of what was needed but left out the areas reflected above. They however, felt there was need to have inputs from students and mentors in coming up with aspects on the instruments.

The student informants and supervisor informants felt TP supervision time was to be increased and had to include a variety of instruments since the 35 to 40 minutes the supervisor was to assess could not allow them to cover all aspects objectively. They suggested the need to have mentors and school based supervisors use different instruments for different aspects.

The student informants and supervisor informants indicated the time given to TP Supervision was to be increased so that a number of issues had to be assessed and there could be more time of exposure to supervision by students. 


\section{CONCLUSIONS}

It can be concluded that the ZOU TP assessment instrument addresses quite amicably the various aspects surrounding teacher preparation.

It can be concluded that the instrument is so packed to be objectively used in the 35 to 40 minutes of a lesson.

It can furthermore be concluded that the time for supervision has to be increased.

It is also concluded that the allocation of marks is not suitable.

\section{RECOMMENDATIONS}

It is in view of the conclusions raised above that the following recommendations are advanced.

1) The use of a variety of supervision instruments at school to cover every area separately.

2) Marks be allocated according to an item rather than blanket marks for an area

3) Assessment of different aspects of teaching over a long time has to be undertaken by both college / university lecturers and school based mentors and supervisors.

4) Further research could be under taken on separate issues related to teaching supervision for example the need of the supervisor to be an expert in the subject area.

\section{References}

Antony, G. \& Walshaw, M. (2009). Characteristics of Effective Teaching of Mathematics. A view from the West. In Journal of Mathematics Education Vol 2 No 2 p 147-164.

Bhowmik, M., Banerjee, B. R. \& Banerjee, J. (2013). Role of Pedagogy in Effective Teaching. In Basic Research Journal of Education Research and Review Vol 2 (1) p1-5.

Celawu, U. M., Salawu, I. D. \& Osuji, U. S. (2008). The Teaching Practice Manual, Abuja: National Open University of Nigeria School of Education.

Coates, D. (1998). Education Production Function Using Instructional Time as an Input. Paper prepared for meetings of Public Choice Society held at New Orleans. Lousiana. March 13-

15.citeseerx.lst.psu.edu/viewdoc/download?dol=10.1.1.50.172519.pdf. accessed 2/9/16.

Cohen, L. (1976). Educational Research In Classrooms and Schools: A Manual of Materials and Methods, London: Harper and Row Ltd.

Fisher, C.(2004). Researching and Writing a Dissertation for Business Learners. Harlow: Pearson Education Ltd.

Flanders (1994). Flanders Interactionist Scale,.New York, Sage.

Goldhammer, R., Anderson, R. H. \& Krajewski. R. J. (1993). Clinical Supervision: Special Methods for the Supervision of Teachers (3rd ED) Fort Worth: Harcourt Brace and Jovanovick College Publishers.

Harris, B. M. (1985). Supervisory Behavior in Education: Research Studies Vol 85, New York: Pergamon Press. Judd, C. M., Smith, E. R., \& Kidder, L. H. (1991). Research Methods in Social Sciences: International Edition (6 ${ }^{\text {th }}$ Ed) Philadelphia: Harcourt Brace Jovanivick College Publishers.

Lewin, K. M. (2004). The Pre- Service Training of Teachers- Does it Meet its Objectives and How can it be Improved. Background Paper for EFM Global Monitoring Report.

Lin, R. L. \& Gronlund, N. E. (1995). Mesurement and Assessment in Teaching (7 $7^{\text {th }}$ Ed) Englewood Cliffs: Merril.

Meador, D. (2014). Qualities of an Effective Teacher. 10 Qualities of an Effective an Effective Teacher.

Mkoba Teachers' College (undated) Teaching Practice Supervision and Assessment Form. Mkoba Teachers' College.

Mudavanhu, Y. (2014). Differences in Perceptions of the Importance of Subject Matter Knowledge and How These Shaped Supervision and Assessment of Student Teachers on Teaching Practice. In RedFame, http://dx.doi.org/10.11114/jets.v3il.589. accessed 17/03/16. 
Muzata, K. K. \& Penda, A. (2010). Pedagogical Experiences of Students on School Teaching Practice- A Study of Two Teachers' Training Institutions on the Copper Belt and Central Provinces of Zambia. International Journal of Sciences Basic and Applied Research Vol 14 No 1: p 187-203.

Rosenshine, B. \& Stevens, R. (1986). Teaching Functions. In Whittrock, M. C. (Ed) Handbook of Research on Teaching ( $3^{\text {rd }}$ ed) New York: Macmillian. P376-391.

Stanford University (undated) Characteristics of Effective Teachers. Charateristics of Effective Teachers- Teaching Commons.htm. Accessed 16/03/16.

The Ministry of Primary and Secondary Education (undated) Narrative Supervision Report on a Teacher.

Tullock, S. (1993). Oxford Complete Word Fiinder. London: The Reader's Digest Association Ltd.

Yin, R. K. (1984). Case Study Research: Design and Method, Newbury Park, CA: Sage .

Walker, R. J. (2008). Twelve Characteristics of Effective Teacher: A Longitudinal, Qualitative' Quasi-Research Study of In-service and Pre-Service Teachers' Opinions. Educational Horozons. Fall p61-67.

Weimer, M. (2009). Effective Teaching strategies: Six Keys to Classroom Excellence, Faculty Focus Higher ED. Teaching strategies from Magna Publications. 